\title{
PENGETAHUAN IBU HAMIL TENTANG PEMERIKSAAN PPIA \\ (PENCEGAHAN PENULARAN IBU KE ANAK) \\ (Di Desa Mojo Kecamatan Mojo Kabupaten Kediri)
}

Rofik Darmayanti ${ }^{1}$

${ }^{1}$ Akademi Kebidanan Dharma Husada Kediri Jawa Timur

\begin{abstract}
Abtrak
HIV (Human Immunodeficiency Virus) merupakan virus yang menyerang jenis sel darah putih yang menyebabkan sistem kekebalan tubuh lemah kemudian berkembang menjadi penyakit yang bernama AIDS. Yang mengancam jiwa tanpa terkecuali ibu hamil. PPIA merupakan program pencegahan penularan Ibu ke Anak. Kurangnya pengetahuan menyebabkan rendahnya minat ibu hamil untuk melakukan pemeriksaan PPIA. Tujuan penelitian adalah mengetahui pengetahuan ibu hamil tentang pemeriksaan PPIA.

Desain penelitian menggunakan Diskriptif pendekatan cross sectional. Penelitian dilakukan pada tanggal 20-24 maret 2018. Populasi yang diteliti adalah semua ibu hamil di Desa Mojo Kecamatan Mojo Kabupaten Kediri. Teknik sampling menggunakan total sampling dan didapatkan 36 responden. Variabel penelitian adalah pengetahuan tentang pemeriksaan PPIA. Pengumpulan data menggunakan kuesioner, pengolahan data (editing, coding, scoring, tabulating)

Hasil penelitian dari 36 responden, 25 responden $(69,4 \%)$ berpengetahuan kurang, 6 responden $(16,6 \%)$ berpengetahuan cukup, 5 Responden berpengetahuan baik $(13,8)$

Berdasarkan penelitian tersebut diharapkan petugas kesehatan meningkatkan pengetahuan responden melalui penyuluhan agar responden memahami dan menerapkan pengetahuan yang didapat dalam kehidupan sehari-hari, sehingga ibu hamil dengan kesadaran bisa melakukan pemeriksaan PPIA.
\end{abstract}

Kata Kunci : Pengetahuan, Ibu Hamil, PPIA 
Pendahuluan

Jumlah kasus baru HIV positif di Indonesia yang dilaporkan cenderung meningkat dan pada tahun 2016 dilaporkan sebanyak 41.250 kasus (Ditjen P2P, Kemenkes RI, 2017). Data Kementerian Kesehatan menunjukkan dari 21.103 ibu hamil yang menjalani tes HIV, 534 $(2,5 \%)$ diantaranya positif terinfeksi HIV. Hasil Pemodelan Matematika Epidemi HIV Kementerian Kesehatan tahun 2012 menunjukkan prevalensi HIV pada populasi usia 15-49 tahun dan prevalensi HIV pada ibu hamil di Indonesia diperkirakan akan meningkat. Jumlah kasus HIV-AIDS diperkirakan akan meningkat dari 591.823 (2012) menjadi 785.821 (2016), dengan jumlah infeksi baru HIV yang meningkat dari 71.879 (2012) menjadi 90.915 (2016). Sementara itu, jumlah kematian terkait AIDS pada populasi 15-49 tahun akan meningkat hampir dua kali lipat di tahun 2016 (Kemenkes, 2012). Berdasarkan hasil penelitian yang dilakukan di Puskesmas Sleman Yogyakarta Ibu hamil yang periksa di Puskesmas Sleman menunjukkan bahwa sebagian besar responden memiliki pengetahuan baik tentang HIV/AIDS yaitu sebanyak 50 responden $(69,4 \%)$ dan sebagian kecil responden memiliki pengetahuan kurang tentang HIV/ AIDS yaitu sebanyak 22 responden (30,6\%) (Annisa dkk, 2015). Dari angka tersebut dapat disimpulkan bahwa pengetahuan ibu tentang HIV/AIDS dalam kategori baik. Pengetahuan ini bisa ibu hamil dapatkan dengan cara masing-masing. Misal mendapat informasi dari petugas kesehatan berupa penyuluhan, pengalaman, kebetulan. Sikap terhadap konseling dan tes HIV/AIDS secara sukarela

di Puskesmas Sleman Yogyakarta dinyatakan bahwa responden yang memiliki pengetahuan baik dan melakukan pemeriksaan PPIA adalah sebanyak 50 responden $(69,4 \%)$, sedangkan responden yang memiliki pengetahuan kurang dan melakukan pemeriksaan PPIA adalah sebanyak 21 responden (29,1\%). Dengan kata lain respon ibu hamil yang melakukan ANC (Antenatal Care) terpadu di Puskesmas Sleman Yogyakarta dalam kategori baik atau setuju terhadap adanya konseling dan tes HIV/AIDS secara sukarela. Jumlah AIDS terbanyak dilaporkan dari Jawa Timur
(17.014). Secara kumulatif, kasus AIDS sampai dengan tahun 2016 sebesar 86.780 kasus (Ditjen P2P, Kemenkes RI, 2017).

Komisi Penanggulangan AIDS

Nasional (KPAN) mengungkap jumlah bayi yang terpapar Human Immunodeficiency Virus (HIV) positif selama 2013 hingga 2017 terbanyak berada di Provinsi Jawa Timur (Republika.co.id, 2017). Di Jawa Timur hasil pemeriksaan terhadap 43.375 perempuan hamil atau ibu hamil, sebanyak 183 atau $0,59 \%$ bumil positif HIV, angka tersebut berdasarkan Dinkes jatim tahun 2014 hingga Maret 2015

(Wordpress, 2015). Berdasarkan hasil proyeksi, jumlah ibu hamil positif yang memerlukan layanan PPIA (Pencegahan Penularan Ibu ke Anak) akan meningkat dari 5.730 orang pada tahun 2010 menjadi 8.170 orang pada tahun 2014 . Hingga tahun 2008 telah tersedia layanan PPIA sebanyak 30 layanan yang terintegrasi dalam layanan KIA (Antenatal Care). Jumlah ibu hamil yang mengikuti tes HIV sebanyak 5.167 orang dimana 1.306 (25\%) dintaranya positif HIV (Komisi Penanggulangan AIDS Nasional, 2010). Menurut Kemenkes (2011) ternyata pengetahuan tentang HIV/AIDS pada

kelompok usia produktif masih rendah, yaitu $11,4 \%$ dari $75 \%$. Sedangkan daripenelitian lain yang dilakukan Chasanah (2012) di RSUD Ibnu Sina Gresik, ibu hamil yang memiliki pengetahuan cukup tentang HIV/AIDS ada 38\%, ibu hamil yang memiliki sikap negatif terhadap VCT ada 56\% (Chasanah, 2012). Berdasar data Dinas Kesehatan Kabupaten Kediri pada kelompok ibu hamil selama tahun 2016 telah di periksa sebanyak $16.047 \mathrm{ibu}$ hamil dengan positif HIV sebanyak 16 ibu hamil $(0,10 \%)$. Penemuan kasus HIV berdasar faktor resiko, penularan HIV melalui heterosek sebesar $84 \%$, homoseks $9 \%$, biseksual $3 \%$ dan perinatal $3 \%$. Menurut golongan umur, penemuan kasus HIV tahun 2016 di kabupaten kediri didominasi oleh kelompok golongan usia produktif, yaitu 2539 tahun sebanyak 594 kasus. Sedangkan usia anak (0-14 tahun) ditemukan 30 kasus (Ditjen P2P Kemenkes RI, 2016). Tingginya angka kejadian HIV/AIDS beberapa diantaranya terjadi karena tingkat pengetahuan masyarakat yang masih rendah, minimnya fasilitas 
kesehatan, dan kondisi seperti kemiskinan, diskriminasi, dan rendahnya status wanita. Kemudian munculnya anggapan masyarakat yang salah terhadap tindakan dan perilaku sehubungan dengan HIV/AIDS semakin menyebabkan penyakit ini menjadi salah satu penyakit yang paling ditakuti (Roidatunisa, 2009). Salah satu upaya untuk menurunkan kejadian

HIV/AIDS adalah dengan program pelayanan konseling dan testing HIV sukarela (Voluntary Counselling and Tesingt-VCT). Saat ini untuk mencegah penularan HIV dari ibu ke bayi, Menteri kesehatan Indonesia mengatakan bahwa wanita hamil perlu ditawarkan atau diprioritaskan untuk melakukan pemeriksaan PPIA kemudian jika hasil $\mathrm{R}$ (reaktif) maka dilakukan pemeriksaan VCT di Rumah sakit, pemeriksaan HIV testing HIV secara sukarela atau dalam bahasa inggris biasa disebut dengan VCT (Voluntary Counseling Testing) merupakan kegiatan konseling secra sukarela, rahasia, terdapat konseling sebelum dan sesudah tes darah untuk HIV dilaboratorium serta adanya persetujuan tertulis inform concent (Maryunani \& Aeman, 2013 : 61).

Layanan konseling dan tes HIV di layanan KIA akan menjangkau banyak ibu hamil, sehingga pencegahan penularan ibu ke anaknya dapat dilakukan lebih awal dan sedini mungkin. Penyampaian informasi dan tes HIV dapat dilakukan oleh semua petugas di fasilitas pelayanan kesehatan kepada semua ibu hamil dalam paket pelayanan ANC terpadu, sehingga akan mengurangi stigma terhadap HIV-AIDS (Kemenkes, 2012).

\section{Metode}

penelitian menggunakan Diskriptif pendekatan cross sectional. Penelitian dilakukan pada tanggal 20-24 maret 2018. Populasi yang diteliti adalah semua ibu hamil di Desa Mojo Kecamatan Mojo Kabupaten Kediri. Teknik sampling menggunakan total sampling dan didapatkan 36 responden. Variabel penelitian adalah pengetahuan tentang pemeriksaan PPIA. Pengumpulan data menggunakan kuesioner, pengolahan data (editing, coding, scoring, tabulating)

Hasil

a. Karakteristik responden berdasarkan umur
Tabel IV.1 Karakteristik Ibu Hamil berdasarkan Umur di Desa Mojo Kecamatan Mojo Kabupaten Kediri

\begin{tabular}{cccc}
\hline NO & $\begin{array}{c}\text { Umur } \\
\text { (tahun) }\end{array}$ & Frekuensi & $\begin{array}{c}\text { Presentase } \\
(\boldsymbol{\%})\end{array}$ \\
\hline $\mathbf{1}$ & $<20$ & 2 & 5,5 \\
\hline $\mathbf{2}$ & $20-35$ & 30 & 83,4 \\
\hline $\mathbf{3}$ & $>35$ & 4 & 11,1 \\
\hline & TOTAL & 36 & 100 \\
\hline
\end{tabular}

Berdasarkan tabel IV.1 dapat diketahui dari 36 responden ibu hamil, sebagian besar ibu hamil berumur 20-35 tahun yaitu sebanyak 30 responden $(83,4 \%)$.

b. Karakteristik responden berdasarkan pendidikan terakhir

Tabel IV. 2 Karakteristik Ibu Hamil berdasarkan Pendidikan Terakhir di Desa Mojo Kecamatan Mojo Kabupaten Kediri

\begin{tabular}{clcc}
\hline $\mathbf{N}$ & $\begin{array}{c}\text { Pendidikan } \\
\text { Terakhir }\end{array}$ & $\begin{array}{c}\text { Frekuens } \\
\mathbf{i}\end{array}$ & $\begin{array}{c}\text { Presentas } \\
\mathbf{e}(\boldsymbol{\%})\end{array}$ \\
$\mathbf{1}$ & Tidak Tamat & 0 & 0 \\
& SD & & \\
$\mathbf{2}$ & SD & 5 & 13,9 \\
$\mathbf{3}$ & SMP & 16 & 44,5 \\
$\mathbf{4}$ & SMA & 14 & 38,9 \\
$\mathbf{5}$ & PERGURUA & 1 & 2,7 \\
& N TINGGI & & \\
& TOTAL & 36 & 100 \\
\hline
\end{tabular}

c. Karakteristik responden berdasarkan pekarjaan

Tabel IV. 3 Karakteristik Ibu Hamil berdasarkan Pekerjaan di DesaMojo Kecamatan Mojo Kabupaten Kediri

\begin{tabular}{|c|c|c|c|}
\hline NO & Pekerjaan & $\begin{array}{c}\text { Frekuen } \\
\text { si }\end{array}$ & $\begin{array}{c}\text { Presentas } \\
\text { e }(\%)\end{array}$ \\
\hline 1 & IRT & 31 & 86,3 \\
\hline 2 & PNS & 1 & 2,7 \\
\hline
\end{tabular}




\begin{tabular}{llll}
\hline $\mathbf{3}$ & SWASTA & 2 & 5,5 \\
$\mathbf{4}$ & WIRASWAS & 2 & 5,5 \\
& TA & & \\
& TOTAL & 36 & 100 \\
\hline
\end{tabular}

Berdasarkan tabel IV. 3 diketahui 36 responden ibu hamil yang diteliti sebagian besar ibu hamil bekerja sebagai ibu rumah tangga yaitu 31 responden $(86,3 \%)$.

d. Karakteristik responden berdasarkan informasi

Tabel IV. 4 Karakteristik Ibu Hamil berdasarkan Informasi di Desa Mojo Kecamatan Mojo Kabupaten Kediri

\begin{tabular}{clcc}
\hline $\mathbf{N}$ & Informas & Frekuens & Presentas \\
$\mathbf{O}$ & $\mathbf{i}$ & $\mathbf{i}$ & $\mathbf{e}(\boldsymbol{\%})$ \\
$\mathbf{1}$ & Pernah & 25 & 69,4 \\
$\mathbf{2}$ & Tidak & 11 & 30,6 \\
& TOTAL & 36 & 100 \\
\hline
\end{tabular}

Berdasarkan tabel IV. 4 diketahui 36 responden ibu hamil yang diteliti sebagian besar ibu hamil Pernah mendapatkan informasi sebanyak $25(69,4 \%)$ dan yang tidak pernah mendapatkan informasi sebanyak 11 $(30,6 \%)$

e. Karakteristik responden berdasarkan sumber informasi

Tabel IV.5 Karakteristik Ibu Hamil berdasarkan Sumber Informasi di Desa Mojo Kecamatan Mojo Kabupaten Kediri

\begin{tabular}{|c|c|c|c|}
\hline $\mathbf{N}$ & Sumber & Frekuens & Presentas \\
\hline O & Informasi & i & e $(\%)$ \\
\hline 1 & $\begin{array}{l}\text { Media } \\
\text { sosial }\end{array}$ & 3 & 8,4 \\
\hline 2 & $\begin{array}{l}\text { Penyuluha } \\
\text { n }\end{array}$ & 16 & 44,5 \\
\hline 3 & Teman & 1 & 2,7 \\
\hline 4 & $\begin{array}{l}\text { Tenaga } \\
\text { kesehatn }\end{array}$ & 5 & 13,8 \\
\hline 5 & $\begin{array}{l}\text { Lain-lain } \\
\text { TOTAL }\end{array}$ & $\begin{array}{l}11 \\
36\end{array}$ & $\begin{array}{c}30,6 \\
100\end{array}$ \\
\hline
\end{tabular}

Berdasarkan tabel IV.5 didapatkan 36 responden ibu hamil mayoritas mengataka mendapatkan sumber informasi melalui penyuluhan yaitu sejumlah 16 responden $(44,5 \%)$.

. Pengetahuan ibu hamil tentang HIV/AIDS

Tabel IV. 6 Pengetahuan ibu hamil tentang PPIA Di Desa Mojo Kecamatan Mojo Kabupaten Kediri

\begin{tabular}{llcc}
\hline $\mathbf{N}$ & $\begin{array}{c}\text { Pengetahua } \\
\mathbf{n}\end{array}$ & $\begin{array}{c}\text { Frekuens } \\
\mathbf{i}\end{array}$ & $\begin{array}{c}\text { Presentas } \\
\mathbf{e}(\%)\end{array}$ \\
$\mathbf{1}$ & Baik & 5 & 13,8 \\
$\mathbf{2}$ & Cukup & 6 & 16,6 \\
$\mathbf{3}$ & Kurang & 25 & 69,4 \\
& TOTAL & 36 & 100 \\
\hline
\end{tabular}

Berdasarkan tabel IV.6 didapatkan 36 responden ibu hamil mayoritas memiliki pengetahuan yang kurang tentang PPIA sebanyak 25 responden $(69,4 \%)$ dan minoritas memiliki pengetahuan baik 5 responden $(13,8 \%)$

\section{Pembahasan}

\section{Pengetahuan ibu hamil tentang PPIA}

Berdasarkan tabel IV.6 maka didapatkan pengetahuan ibu hamil tentang PPIA di Desa Mojo Kecamatan Mojo Kabupaten Kediri sejumlah 36 responden, pengetahuan dalam kategori baik yaitu sejumlah 5 responden $(13,8 \%)$ yang memiliki pengetahuan cukup 6 responden $(16,6 \%)$, dan yang memiliki pengetahuan kurang sejumlah 3 responden $(69,4 \%)$

Berdasarkan hasil penelitian diatas dapat diketahui dari 36 responden yang diteliti mayoritas berpengetahuan Kurang yaitu sejumlah 25 responden $69,4 \%$ ).

Pengetahuan merupakan hasil dari tahu dan ini terjadi setelah orang melakukan penginderaan terhadap suatu obyek tertentu. Penginderaan terjadi melalui panca indera manusia yakni indera penglihatan, pendengaran, penciuman. Sebagian besar pengetahuan manusia diperoleh melalui mata dan telinga (Wawan dan Dewi, 2010: 11).

Pengetahuan yang dimiliki responden dalam penelitian sama seperti yang dikemukakan oleh teori yaitu pengetahuan 
dimana seseorang menjadi tahu terhadap suatu objek seperti halnya pada penelitian ini, ibu hamil tahu PPIA karena ibu hamil memiliki pengetahuan tentang PPIA

Berdasarkan hasil penelitian pengetahuan dipengaruhi oleh umur. Didapatkan dari tabel IV.1 bahwa umur merupakan mayoritas 20-35 tahun yaitu 30 responden $(83,4 \%)$.

Usia mempengaruhi daya tangkap dan pola pikir seseorang. Semakin bertambah usia akan semakin berkembang pula daya tangkap dan pola pikirnya sehingga pengetahuan yang diperolehnya semakin membaik. Pada usia madya, individu akan lebih berperan aktif dalam masyarakat dan kehidupan sosial lebih banyak melakukan persiapan demi suksesnya upaya menyesuaiakan diri menuju usia tua (Riyanto, $2014:$ 7).

Berdasarkan teori yang telah dijelaskan tersebut, umur sangat dihubungkan dengan pengalaman semakin dewasa umur seseorang maka semakin banyak informasi yang dijumpai dan semakin banyak hal yang dikerjakan sehingga banyak pengetahuan, banyak pengalaman. Selain umur pengetahuan juga dipengaruhi oleh pendidikan,

berdasarkan tabel IV. 2 sebagian besar pendidikan terakhir responden yaitu SMP sejumlah 16 responden $(44,5 \%)$.

Pendidikan adalah suatu usaha untuk mengembangkan kepribadian dan kemampuan didalam dan diluar sekolah baik formal maupun non formal. Pendidikan adalah sebuah proses perubahan sikap dan tata laku seseorang atau kelompok dan juga usaha mendewasakan manusia melalui upaya pengajaran dan pelatihan. Dengan pendidikan tinggi, maka seseorang akan cenderung untuk mendapatkan informasi yang masuk semakin banyak pula pengetahuan yang didapat tentang kesehatan (Riyanto, $2014: 7$ ).

Dalam kenyataan pengetahuan baik meskipun pendidikan SMP, hal ini disebabkan oleh informasi yang pernah didapatkan ibu mengenai PPIA yang diperoleh dari berbagai informasi baik dari penyuluhan yang diberikan oleh tenaga kesehatan maupun dari berbagai macam media sosial. Maka dari itu pendidikan sangat mempengaruhi pengetahuan seseorang karena dari pendidikan seseorang dapat mengembangkan kepribadian diri dan sebuah proses perubahan sikap diri seseorang.

Pekerjaan juga mempengaruhi pengetahuan seseorang, berdasarkan tabel IV.3 maka didapatkan hasil pekerjaan responden mayoritas tidak bekerja atau sebagai ibu rumah tangga yaitu sejumlah 31 responden $(86,3 \%)$.

Menurut Wawan \& Dewi (2010), pekerjaan bukanlah sumber kesenangan, tetapi lebih banyak merupakan cara mencari nafkah yang membosakan, berulang dan banyak tantangan. Sedangkan bekerja merupakan kegiatan yang menyita waktu.

Pekerjaan sebagai ibu rumah tangga sangat mempunyai pengaruh terhadap kehidupan berkeluarga karena ibu rumah tangga mempunyai peran yang sangat penting dan mempunyai tanggungjawab untuk mengurus kegiatan rumah tangga dan keluarga. Bagi ibu-ibu yang bekerja atau sebagai ibu rumah tangga akan lebih sedikit memahami tentang HIV/AIDS karena kesibukan untuk mengatur kegiatan rumah dan bagi ibu-ibu yang tidak bekerja atau sebagai ibu rumah tangga, ibu akan memiliki banyak waktu luang untuk mendapatkan informasi dan menangkap pengetahuan tentang PPIA dari berbagai informasi.

selain dipengaruhi oleh pekerjaan, pengetahuan juga dipengaruhi oleh tersedianya informasi. Berdasarkan tabel IV.4 didapatkan mayoritas

responden di Desa Mojo Kecamatan Mojo Kabupaten Kediri sudah pernah mendapatkan informasi tentang HIV/AIDS yaitu sejumlah 25 responden $(69,4 \%)$ dan berdasarkan tabel IV.5 didapatkan bahwa responden menerima informasi melalui penyuluhan yaitu sejumlah 16 responden $(44,5 \%)$.

Informasi yang diperoleh baik dari pendidikan formal maupun nonformal dapat memberi pengaruh jangka pendek (immendiate impact) sehingga menghasilkan berubahan atau peningkatan pengetahuan (Riyanto, $2014: 5$ ).

Namun hal tersebut masih dipengaruhi oleh melekatnya tradisi-tradisi tertentu. Dengan banyaknya informasi yang tersedia baik melalui penyuluhan, media sosial maupun petugas kesehatan diharapkan akan membantu meningkatkan pengetahuan. Informasi yang didapat akan berpengaruh baik pada responden, karena informasi yang dianggap sangat penting 
dan benar sehingga menghasilkan perubahan atau peningkatan pengetahuan. Berkembangnya teknologi akan menyediakan berbagai media masa sebagai sumber informasi yang dapat mempengaruhi pengetahuan masyarakat tentang inovasi baru.

\section{Simpulan}

Berdasarkan penelitian yang dilakukan di Desa Mojo Kecamatan Mojo Kabupaten Kediri dari 36 responden yang dijadikan sampel penelitian

dengan mengambil data melalui kuesioner maka pengetahuan ibu hamil pemeriksaan PPIA di Desa Mojo Kecamatan Mojo Kabupaten Kediri diambil kesimpulan sebagai berikut :

1. Pengetahuan ibu hamil tentang HIV/AIDS dalam kategori kurang sebanyak 25 responden $(69,4 \%)$.

\section{DAFTAR PUSTAKA}

Ariani, A. P. (2014). Aplikasi Metodologi Penelitian Kebidanan Dan Kesehatan Reproduksi. Yogyakarta: Nuha Medika.

Anik Maryunani \& Aeman. (2013). Buku Saku Pencegahan Penularan HIV dari Ibu ke Bayi Penatalaksanaan Di Pelayanan Kebidanan . Jakarta: Trans $\quad$ Info Media.

Budiman \& Agus Riyanto (2014). Kapita Selekta Kuesioner Pengetahuan dan Sikap dalam Penelitian Kesehatan. Jakarta Selatan: Salemba Medika.

Chasanah, 2012, Hubungan Pengetahuan Ibu Hamil tentang HIV/AIDS dengan Sikap terhadap VCT di RSUD Ibnu Sina Gresik, Surabaya: Universitas Airlangga.

Katiandagho Desmon, S. M. (2015). Epidemiologi HIV-AIDS. Bogor: In Media. Hidayat, A. A. (2014). Metode Penelitian Kebidanan dan Teknik Analisa Data. Jakarta Selatan: Salemba Medika.

Kementrian Kesehatan RI, 2017. Laporan Perkembangan HIV-AIDS dan Infeksi Menular Seksual (PIMS) Triwulan I Tahun 2017. Jakarta : Direktorat Jendral Pencegahan dan Pengendalian Penyakit.

Kementrian Kesehatan RI, 2012. Pedoman Nasional Pencegahan Penularan HIV dari
Ibu ke Anak. Jakarta : Direktorat Jendral Pengendalian Penyakit dan Penyehat Lingkungan.

Kementrian Kesehatan RI, 2016. Profil Kesehatan Kabupaten Kediri. Kediri: Dinas Kabupaten Kediri.

Notoatmodjo, S., 2010. Metodologi Penelitian Kesehatan, Jakarta: Rineka Cipta. , 2012. Metodologi Penelitian Kesehatan, Jakarta: Rineka Cipta.

Nasronudin, 2014. Pendekatan Biologis Molekuler, Klinis dan Sosial HIV\&AIDS, Surabaya: Airlangga University Press

Nursalam, Kurniawati, ND, 2008. Asuhan Pada Pasien Terinfeksi HIV/AIDS,

Wawan \& Dewi. (2010). Teori \& Pengukuran Pengetahuan, Sikap, dan Periklaku. Yogyakarta: Nuha Medika

Wiratna Sujarweni, V (2014). Metodologi Penelitian, Lengkap, Praktis, dan Mudah dipahami. Yogyakarta: PT Pustaka Baru

Annisaa'Nurmasari, F. F. (2015). Tingkat Pengetahuan Ibu Hamil tentang HIV/AIDS dengan Perilaku. JOURNAL NERS, 48. diakses dari: http://www.ejournal.almaata.ac.id/index.php /JNKI/article/view/100 [2 maret 2018]

Aminah, R. L. 2017 . Bayi Terpapar HIV di Jawa Timur. Artikel. [Online] from : http://nasional.republika.co.id/berita/nasiona 1/umum/17/11/24/ozwp1w384-bayiterpapar-hiv-tertinggi-di-jawa-timur $\quad$ [2 Maret 20181

Anikmatul, 2017. HIV (Human Immunodeficiency Virus)/ AIDS (Acquaired Immuno Deficiency Syndrom) page 01, Retrieved from:http://scholar.unand.ac.id/28859/2/ BAB\%201.pdf. [2 Maret 2018]

Bidan Share, 2012. Definisi Kehamilan. (18 November 2012) Retreived https://bidanshare.wordpress.com. [ 2 Maret 2018]

Roidatunisa. 2009, Peranan World Health Organization (WHO) melalui Global Programme on AIDS dalam Menangani Kasus HIV/AIDS di Indonesia, Bandung, Retrieved: March 9, 2013 from http://elib.unikom.ac.id/download.php?id=5 7813/jbptunikompp-gdl-roidatunis-19690-1\begin{tabular}{llll}
\hline pdfroid-8.pdf $\quad[26$ & Januari & 2018 \\
\hline
\end{tabular} 
